\title{
MANAJEMEN SARANA DAN PRASARANA DI SMP NEGERI 255 JAKARTA \\ (JAKARTA, 2017)
}

\author{
Angga Harizki, Dr. Wahyu Sri Ambar Arum, MA, Dr. Neti Karnati, M.Pd
}

anggaharizki187@gmail.com

\begin{abstract}
The research aimed to identify and obtain an overview of the maintenance and inventory of educational facilities. This research was conducted in in SMP Negeri 255 on May 2015 through June 2016. The research used a qualitative approach with descriptive methods. Data was collected through interviews, observation and documentation. Source data from this study came from key informants that the vice principal fields of infrastructure, while supporting informant I is treasurer of goods and informants II is the principal. Results from the study showed that (1) Mechanical maintenance of educational facilities that do SMP Negeri 255 Jakarta include awareness, understanding, organizing, implementation and data collection. Problems that occur in the technical maintenance of educational facilities is the lack of a clear division of labor, funding needs due to late disbursement of BOS and BOP, and difficulty to obtain experts. (2) Procedures inventory of educational facilities was conducted on the recording, coding and inventory evaluation. Problems that occur in the inventory procedure for school infrastructure is often the goods delivered are not in accordance with the required specifications of the school, so that has caused delays in the process of recording goods.
\end{abstract}

Keywords: Management, Maintenance, Inventory, Infrastructures Education

\section{Pendahuluan}

Pendidikan menjadi inti dari kehidupan manusia dan pendidikan pula menjadi inti dari sebuah pembangunan negara. Saat ini pendidikan menjadi suatu tolak ukur dari seluruh kegiatan atau aktifitas manusia. Pendidikan merupakan usaha agar manusia dapat mengembangkan segala potensi yang ada pada dirinya melalui proses pembelajaran dan cara lain yang dikenal dan diakui oleh masyarakat. Pendidikan merupakan suatu proses pendewasaan manusia, mengubah manusia dari yang tidak tahu menjadi tahu. Pendidikan juga menjadi alat pengembangan bagi manusia itu sendiri. Dengan adanya pendidikan yang baik dan berkualitas, diharapkan manusia dapat memperbaiki dan memilah mana yang baik maupun yang tidak berdasarkan landasan pemikirannya. Perlu diyakini bahwasannya pendidikan yang dikelola dan dilaksanakan dengan baik mampu melahirkan sebuah bangsa yang besar, karena pendidikan tersebut akan melahirkan sumber daya manusia yang berkualitas dan berkompetensi. Sekolah adalah lembaga resmi pendidikan yang bertugas menyelenggarakan proses pendidikan dan pembelajaran. Lembaga sekolah diamanatkan untuk membentuk karakter dan kecerdasan generasi penerus bangsa. Namun pada praktiknya, sekolah tidak hanya berurusan pada aspek belajar mengajar saja. Salah satu hal yang urgen untuk diperhatikan adalah persoalan manajemen sekolah. Persoalan manajemen terkait dengan kepentingan efektivitas dan efisiensi 
penyelenggaraan pendidikan. Dengan demikian, tanpa sebuah pengelolaan manajemen yang baik, kecil kemungkinan sekolah mampu memenuhi standar pendidikan.

Sebagai lembaga pendidikan, sekolah memerlukan dukungan sarana dan prasarana pendidikan. Sarana dan prasarana pendidikan merupakan material pendidikan yang sangat penting dan menjadi satu dari delapan standar nasional pendidikan. Banyak sekolah memiiki sarana dan prasarana pendidikan yang lengkap sehingga sangat menunjang proses pendidikan di sekolah. Baik guru maupun siswa, merasa terbantu dengan adanya fasilitas tersebut. Namun sayangnya, kondisi tersebut tidak brlangsung lama. Tingkat kualitas dan kuantitas sarana dan prasarana tidak dapat dipertahankan secara terus-menerus. Sementara itu, bantuan sarana dan prasarana pun tidak datang setiap saat. Oleh karena itu, dibutuhkan upaya pengelolaan sarana dan prasarana secara baik agar kualitas dan kuantitas sarana dan prasarana dapat dipertahankan dalam waktu yang relatif lebih lama.

Keberadaan sarana dan prasarana sekolah bukan hanya untuk digunakan saja, tetapi juga untuk dipelihara secara teratur. Sarana dan prasarana akan mengalami penyusutan kualitas dari waktu ke waktu. Sejak barang diterima dari penjual atau pemborong, sejak itu pula barang tersebut akan mengalami penyusutan kualitas. Baik kualitas maupun kuantitas sarana dan prasarana pendidikan akan menurun drastis jika tidak dikelola dengan pengetahuan yang cukup.

Berdasarkan kondisi tersebut, lembaga pendidikan dituntut untuk mampu mengelola semua sarana dan prasarana yang ada. Kegiatan pengelolaan sarana dan prasarana diantaranya pemeliharaan dan inventarisasi, agar sarana dan prasarana yang ada dapat digunakan sesuai dengan masa manfaat dari barang tersebut.

SMP Negeri 255 Jakarta yang terletak di Jl. Raden Inten II RT 008 RW 10, Duren Sawit, Jakarta Timur merupakan salah satu sekolah favorit di Jakarta Timur yang memiliki sarana dan prasarana yang memadai dan memiliki berbagai prestasi di berbagai bidang akademik dan non akademik, salah satu prestasi terbarunya adalah saat Ujian Nasional 2015 nilai sekolah tersebut mendapat peringkat keempat Se-DKI Jakarta.

SMP Negeri 255 Jakarta juga merupakan sekolah yang dikenal memiliki sarana dan prasarana yang lengkap. Namun ternyata pada saat tahun ajaran 2014/2015, keadaan ruang perpustakaan sekolah dalam keadaan rusak parah, dan diketahui ternyata memang sekolah tidak tahun itu tidak memprogramkan pemeliharaan ruang perpustakaan hingga akhirnya terabaikan selama satu tahun. Pada tahun ajaran selanjutnya barulah ruang perpustakaan mengalami perbaikan.

Mengacu pada latar belakang yang telah diuraikan diatas, penulis ingin mengetahui bagaimana SMP Negeri 255 Jakarta memperlakukan sarana dan prasarana lainnya yang ada. Oleh karena itu, penulis tertarik untuk melakukan penelitian dengan judul "Manajemen Sarana dan Prasarana Pendidikan di SMP Negeri 255 Jakarta".

\section{Tinjauan Pustaka}

Menurut Wahyu Sri Ambar Arum (2007 : 6-7) Sarana pendidikan adalah semua peralatan atau fasilitas yang langsung digunakan dalam proses belajar mengajar agar tujuan pendidikan dapat tercapai. Sedangkan prasarana pendidikan adalah alat yang tidak langsung yang digunakan untuk mencapai tujuan pendidikan. Menurut Syaiful Sagala (2007 : 219) sarana dan prasarana erat kaitannya dengan 
perlengkapan dan peralatan. Perlengkapan pendidikan di sekolah adalah semua benda bergerak maupun tidak bergerak, yang diperlukan untuk menunjang penyelenggaraan proses belajar mengajar baik secara langsung maupun tidak langsung.

Menurut Ary H. Gunawan (2011 : 114) Administrasi sarana dan prasarana pendidikan merupakan keseluruhan proses kegiatan yang direncanakan dan diusahakan secara sengaja dan bersungguh-sungguh serta pembinaan kontinu terhadap bendabenda pendidikan, agar senantiasa siap pakai (ready for use) dalam proses belajar mengajar sehingga proses belajar mengajar semakin efektif dan efisien guna membantu tercapainya tujuan pendidikan yang telah ditetapkan.

Dalam pelaksanaan manajemen perlu diperhatikan beberapa prinsip yaitu: efisiensi, efektivitas, dan administratif

Menurut Ibrahim Bafadal (2004 : 2) menyebutkan bahwa proses atau fungsi-fungsi manajemen perlengkapan sekolah terdiri dari: pengadaan, pendistribusian, penggunaan dan pemeliharaan, inventasasi, dan penghapusan.

Sebagai lembaga pendidikan, sekolah memerlukan dukungan sarana dan prasarana pendidikan. Sarana dan prasarana pendidikan merupakan material pendidikan yang sangat penting. Banyak sekolah memiliki sarana dan prasarana pendidikan yang lengkap sehingga sangat menunjang proses pendidikan. Oleh karena itu, dibutuhkan upaya manajemen sarana dan prasarana secara efektif dan efisien agar kualitas dan kuantitas sarana dan prasarana dapat dipertahankan dalam waktu yang relatif lama.

Aktivitas penting dalam manajemen sarana dan prasarana adalah pemeliharaan dan inventarisasi. Menurut Barnawi dan M. Arifin (2012 : 74) Pemeliharaan adalah kegiatan untuk melaksanakan pengurusan dan pengaturan agar semua barang selalu dalam keadaan baik dan siap untuk digunakan secara berdayaguna dan berhasil guna. Pemeliharaan mrupakan kegiatan penjagaan atau pencegahan dari kerusakan suatau barang, sehingga barang tersebut kondisinya baik dan siap digunakan. Pemeliharaan mencakup segala daya upaya yang terus menerus untuk mengusahakan agar peralatan tersebut tetap dalam keadaan baik.

Tahapan dalam memelihara sarana dan prasarana sekolah dapat dirumuskan menjadi 5P, yaitu Penyadaran, Pemahaman, Pengorganisasin, Pelaksanaan dan Pendataan.

Inventarisasi secara definitif menurut Ibrahim Bafadal (2004 : 55) adalah pencatatan dan penyusunan daftar barang milik negara secara sistematis, tertib, dan teratur berdasarkan ketentuan-ketentuan dan pedoman yang berlaku. Dilanjutkan , inventarisasi didefinisikan sebagai pencatatan sarana dan prasarana milik negara, namun sebenarnya yang perlu diinventarisasikan tidak hanya itu. Semua barang atau perlengkapan sekolah, baik barang-barang habis pakai maupun tahan lama, baik barang-barang milik negara ataupun milik sekolah, baik yang bergera atau tidak bergerak, yang murah atau yang mahal harus diinventarisasi dengan tata cara yang berlaku.

Menurut Ary H Gunawan (2011 : 143) dalam kegiatan inventarisasi, ada beberapa tahapan kerja sehingga proses inventarisasi ini dapat berjalan dengan baik, sebagai berikut, (1) Mencatat semua barang inventaris di dalam "Buku Induk Inventaris" dan buku pembantu "Buku Golongan Inventaris". Memberikan koding pada barang-barang yang diinventarisasikan. (3) Membuat laporan triwulan tentang mutasi barang. 
inventaris. (5) Membuat daftar rekapitulasi tahunan.

\section{Metodologi Penelitian}

Tujuan khusus yang ingin dicapai melalui penelitian ini yaitu untuk mengetahui pemeliharaan, inventarisasi, serta kendala-kendala dalam pemeliharaan dan inventarisasi sarana dan prasarana pendidikan di SMP Negeri 255 Jakarta. Pendekatan penelitian yang digunakan oleh peneliti adalah pendekatan kualitatif dengan metode deskriptif. Penelitian ini dilakukan di SMP Negeri 255 Jakarta yang terletak di Jl. Raden Inten RT 008 RW 10, Duren Sawit, Jakarta Timur.

Jenis data yang dikumpulkan dan digunakan dalam penelitian ini adalah data kualitatif. Data yang dikumpulkan bukan merupakan angka-angka melainkan berupa kata-kata dan gambar berdasarkan fakta dan kondisi yang terdapat dilapangan yang teramati oleh indera. Data yang dihimpun pada penelitian ini berupa hasil observasi yaitu pengamatan yang dilakukan pada saat kegiatan manajemen sarana dan prasarana pendidikan dilakukan. Selain itu data juga didapat melalui hasil studi dokumentasi dan melalui hasil wawancara yang dilakukan dengan beberapa informan.

Sumber data penelitian kualitatif dibagi menjadi dua yaitu sumber data primer dan sumber data sekunder. Sumber data primer terdiri dari data inti berasal dari sumber asli yang diperoleh secara langsung dari narasumber, pelaku, atau pihak yang terkait dengan objek penelitian melalui hasil wawancara secara mendalam, serta hasil observasi partisipatif peneliti selama di lapangan. Dalam penelitian ini yang dijadikan informan yaitu: 1) Wakil Bendahara Barang SMP Negeri 255 Jakarta sebagai key informan, 2) Kepala SMP 255 Jakarta sebagai informan pendukung I, 3) Kepala SMP Negeri
255 Jakarta sebagai informan pendukung II.

Teknik pemilihan informan dilakukan dengan teknik snowball sampling. Selain sumber data primer, terdapat sumber data sekunder yang diperoleh melalui dokumen-dokumen pendukung yang diambil dari studi dokumentasi yang berkaitan dengan objek penelitian dan pengamatan. Sebelum melaksanakan penelitian ini peneliti melaksanakan tahap Pra Lapangan dimulai dari (1) Menyusun Rancangan Penelitian, (2) Memilih Lokasi Penelitian, (3) Mengurus Surat Perizinan, (4) Menjajaki dan Menilai Keadaan Lapangan, (5) Memilih dan Memanfaatkan Informan, Menyiapkan Perlengkapan Penelitian.

Tahap selanjutnya yakni tahap Pekerjaan Lapangan dimulai dari (1) Memahami latar penelitian, (2) Memasuki lapangan, (3) Berperan Serta dan Mengumpulkan Data.

Tahap selanjutnya yakni tahap analisis data dengan langkah - langkah yaitu reduksi data, penyajian data, dan menarik kesimpulan (verifikasi). Tahapan ini kemudian diakhiri dengan pemeriksaan atau pengecekan keabsahan data dengan tahapan (1) Kredibilitas data, menggunakan triangulasi sumber, teori dan metode, (2) Transferabilitas, Peneliti memaparkan dan menyajikan data mengenai subfokus yaitu: Perencanaan, pelaksanaan, dan evaluasi kurikulum kedalam bentuk uraian yang jelas, sistematis dan akurat dengan menggun metode penulisan teks naratif, gambar, bagan dan tabel, (3) Dependabilitas, untuk mengukur tingkat kesulitan antara data yang satu dengan data yang lain. Peneliti menuliskan hasil penelitian secara sistematis sesuai dengan subfokus yang diteliti, (4) Komformabilitas, peneliti kembali melakukan pengecekan data yang diperoleh melalui wawancara, observasi dan studi dokumentasi, dan peneliti 
mengkonfirmasi kembali hasil yang sudah didapat.

\section{Hasil dan Pembahasan}

Sekolah Menengah Pertama Negeri 255 Jakarta, merupakan sebuah Sekolah Menengah Pertama Negeri yang terlertak di Jl. Raden Inten 2 Kecamatan Duren Sawit, Jakarta Timur. Berdiri pada tanggal 1 juli 1987 dengan luas lahan $5.825 \mathrm{~m}^{2}$ dan luas bangunan 3.264 $\mathrm{m}^{2}$. SMP Negeri 255 Jakarta memiliki kode NPSN 20103580. Saat ini memiliki akreditasi A.

Pada tahun 1998 SMP Negeri 255 ditetapkan sebagai salah satu sekolah Unggulan di DKI Jakarta. Hal ini berdasarkan Surat Keputusan Direktur Pendidikan Lanjutan Pertama No 960/C3/Kp. 2005.

SMP Negeri 255 Jakarta saat ini diberi kepercayaan sebagai Sanggar MGMP/MKS Kecamatan Duren Sawit, Sanggar 040, Sub Rayon Ujian Nasional 12 dan Kegiatan di Lingkungan SUDIN DIKNAS Kotamadya Jakarta Timur Wilayah Utara (Timur Satu) yang meliputi Kecamatan Duren Sawit, Kecamatan Jatinegara, Kecamatan Matraman, Kecamatan Pulogadung dan Kecamatan Cakung.

Pada tahun ajaran 2015/2016, SMP Negeri 255 Jakarta memiliki 380 siswa laki-laki dan 521 siswi perempuan, menjadikan jumlah keseluruhan pelajar 901 orang. Saat ini SMP Negeri 255 Jakarta memiliki 39 ruangan, dengan ruang belajar sebanyak 25 ruang yang semua kelas tersebut telah berbasis IT.

Sedangkan untuk melaksanakan KBM di SMP Negeri 255 Jakarta mempunyai guru yang memiliki potensi di setiap bidang studi yang diajarkan, begitu juga dengan pengelolaan sekolah yang baik didukung dengan adanya staf dan karyawan yang dapat menunjang kualitas sekolah. Saat ini jumlah guru dan karyawan di SMP Negeri 255
Jakarta sebanyak 72 orang yang terdiri dari 1 kepala sekolah, 51 orang guru, 11 pegawai tata usaha, 5 pramubakti dan 4 satpam.

Visi SMP Negeri 255 Jakarta adalah Mempersiapkan insan yang beriman, bertaqwa, cerdas, kompetitif dan Berwawasan Global. Sedangkan misinya adalah (1) Membina dan meningkatkan kegiatan keagamaan, (2) Menyediakan dan mengoptimalkan pemanfaatan akses informasi dan komunikasi sebagai upaya pengembangan wawasan warga sekolah, (3) Meningkatkan kualitas SDM pendidik dan tenaga kependidikan untuk merealisasikan tuntutan Standar Nasional Kependidikan, (4) Menanamkan konsep ilmiah dan semangat berkompetisi, (5) Membimbing, melatih dan mengikutsertakan siswa dalam berbagai lomba baik intra maupun ekstrakurikuler disemua tingkatan untuk meningkatkan kreatifitas dan daya saing global.

Adapun sarana dan prasarana yang ada di SMP Negeri 255 Jakarta yaitu: 25 ruang kelas, 1, ruang perpustakaan, 1 ruang kepala sekolah, 1 ruang wakil kepala sekolah, 1 ruang tata usaha, 1 ruang guru, 1, ruang multimedia, 1 ruang UKS, 1 ruang laboratorium bahasa, 1 ruang OSIS, 1 ruang laboratorium IPA, 1 ruang Sanggar/Sub Rayon, 1 ruang BK, 1 ruang Praktek Komputer, 4 ruang toilet, 2 lapangan.

Pemeliharaan sarana dan prasarana di SMP Negeri 255 Jakarta (1) Penyadaran, yang dilakukan adalah dengan memanfaatkan momen-momen tertentu untuk melakukan sosialisasi pentingnya pemeliharaan sarana dan prasarana, seperti rapat kerja, upacara bendera, saat KBM bahkan saat berpapasan di waktu istirahat dan jam luar sekolah. Kegiatan penyadaran yang dilakukan adalah berupa memberikan penjelasan manfaat memiliki sarana dan prasarana yang baik dan apa dampak 
buruknya jika tidak ada pemeliharaan sarana dan prasarana, dan pemasangan pesan-pesan pengingat dan tata tertib penggunaan sarana dan prasarana di tempat-tempat tertentu. Namun di samping itu, tentunya untuk menyadarkan seluruh warga sekolah agar mau memelihara sarana dan prasarana yang ada di sekolah membutuhkan koordinasi dan kerja sama antarpihak yakni dengan guru, staf sekolah, pramubakti dan keamanan sekolah.

dalam pemahaman pemeliharaan sebenarnya hampir sama dengan penyadaran pemeliharaan yaitu dengan memanfaatkan momen momen tertentu untuk melakukan sosialisasi pentingnya pemeliharaan sarana dan prasarana. Hanya saja dalam kegiatan pemahaman lebih menekankan mengenai permasalahan apa yang biasa ditimbulkan oleh stakeholders terhadap sarana dan prasarana yang dimiliki oleh sekolah. Untuk meningkatkan pemahaman pentingnya memelihara sarana dan prasarana pendidikan, sekolah memiliki 2 kegiatan pemahaman yang rutin dilakukan. Pertama, menjelaskan masalah yang dihadapi dalam pemeliharaan sarana prasarana, seperti perilaku buruk yang sering pengguna sarana prasarana lakukan. Kedua, menjelaskan program kegiatan pemeliharaan yang akan dilakukan kepada stakeholders, sehingga dapat menjadi perhatian bersama.

(3) Pengorganisasian, SMP Negeri 255 Jakarta tidak memiliki struktur organisasi dan pembagian peran yang detail. Meskipun begitu, tetapi sekolah tetap memiliki pengorganisasian sederhana, yakni kepala sekolah sebagai penanggung jawab, wakil kepala sekolah bidang sarana dan prasarana ketua, 2 orang guru yang secara sukarela menjadi tim sarana dan prasarana sebagai pelaksana pemeliharaan.
(4) Pelaksanaan, pelaksanaan pemeliharaan terbagi menjadi pemeliharaan rutin dan pemeliharaan berkala. Pemeliharaan rutin bertujuan untuk menjaga sarana dan prasarana agar tetap dalam kondisi nyaman dan bertahan lama. Pemeliharaan rutin merupakan sarana pendidikan kepada murid untuk selalu memelihara lingkungan sekitarnya, seperti dilakukannya program piket kelas. Untuk pemeliharaan berkala bertujuan untuk merawat sekaligus memperbaiki jika ada kerusakan agar sarana ada prasarana dapat berfungsi kembali sebagaimana mestinya. Kegiatan perawatan dapat dilakukan oleh warga sekolah sendiri, tetapi untuk perbaikan dilakukan oleh tenaga ahli.

(5) Pendataan, hal yang dilakukan selama pendataan adalah memonitoring program kegiatan sarana dan prasarana yang telah dibuat selama satu tahun ajaran. Di rencana program kegiatan sarana dan prasarana juga sudah ada kegiatan pemeliharaan apa saja yang akan dilaksanakan selama satu tahun ajaran. Misalnya ada tambahan atau ada yang tidak terlaksana itu juga akan laporannya ke dalam format monitoring program kerja. Di situ kita data kegiatan pemeliharaan apa saja yang tidak bisa terlaksana, dan apa penyebabnya. Kemudian, tindak lanjutnya yaitu, hasil pendataan pemeliharaan yang berupa format monitoring program kerja, dapat dijadikan bahan evaluasi untuk penyusunan rencana program kerja sarana dan prasarana tahun berikutnya. Hasil pendataan akan sangat bermanfaat untuk megoptimalkan penggunaan sarana dan prasarana dan untuk kepentingan pelaporan.

Inventarisasi sarana dan prasarana di SMP Negeri 255 Jakarta, (1) Pencatatan, Tahap pertama dalam pencatatan sarana dan prasarana yang ada di sekolah adalah menyesuaikan antara barang yang diterima dengan 
data/dokumennya. Hal tersebut dilakukan guna mengetahui ada atau tidaknya kebermanfaatan barang baru tersebut di sekolah, selain itu perlu dicek apakah barang tersebut bernilai mahal atau tidak, agar nantinya barang tersebut dapat penempatan yang lebih baik, setelah itu sekolah juga harus segera mencatat dari mana asal barang dikirimkan dan tahun berapa barang diterima. Tahap kedua dari proses pencatatan sarana dan prasarana adalah melakukan pencatatan barang inventaris yang diterima ke dalam buku Induk Inventaris. Barang yang akan dicatat kedalam buku induk inventaris adalah barang yang tahan lama yang usianya lebih dari 1 tahun, sementara yang usianya kurang dari 1 tahun atau disebut barang habis pakai dan dicatat dalam buku pembantu. Setelah semua tahap pencatatan dan pengelompokkan barang usai, data barang-barang yang telah dicatat akan dimasukkan ke dalam sebuah database milik sekolah sebagai acuan daftar aktiva sarana-prasarana sekolah.

(2) Pengkodean, Tahapan awal dari pemberian kode barang dimulai dengan menganalisis perolehan asal sarana dan prasarana yang dikirim. Asal perolehan sarana dan prasarana yang diterima akan berpengaruh terhadap kode barang yang akan dicantumkan, misalkan barang dari Dinas akan diberi kode Dinas.../tahun perolehan, jika dari Sudin akan diberi kode SDJT.../tahun perolehan, dan jika berasal dari komite maka terlebih dahulu akan dilakukan berita acara serah terima pemanfaatan dan kepemilikan barang dari komite ke sekolah. Tahap selanjutnya adalah akan dikelompokan berdasarkan jenis barang. Seperti kode meja memiliki jenis kode tersendiri. Setelah itu sarana dan prasarana tersebut disesuaikan sesuai dengan rujukan kode barang yang diterbitkan oleh PEMDA DKI Jakarta. Tahap yang terakhir dari proses pemberian kode sarana dan prasarana adalah penulisan kode pada label dan menempel label tersebut pada barang.

(3) Evaluasi, dilakukan oleh salah seorang Bendahara Barang dan didampingi oleh staf tim sarana dan prasarana SMP Negeri 255 Jakarta. Evaluasi ini dilakukan secara berkala, yaitu setiap satu tahun sekali dan dilakukan di tiap akhir tahun ajaran, tepatnya di Bulan Juni. Tujuan dibuatnya pelaporan kegiatan inventarisasi adalah mengetahui terpenuhi atau tidaknya analisis kebutuhan yang terkait dengan sarana prasarana pendidikan, mempermudah penanganan bila terjadi kerusakan terhadap sarana prasarana pendidikan, sebagai laporan untuk sumber/pemberi barang bahwa barang sudah diterima, bagaimana pemanfatan barang di sekolah". Proses pelaporan kegiatan inventarisasi adalah dengan, membuat daftar barang secara berkala baik dalam bentuk KIB (Kartu Inventaris Barang) maupun KIR (Ruangan), Stok Barang, dan lain-lain. Laporan kegiatan inventarisasi akan diserahkan kepada kepala sekolah dan dinas terkait.

Kendala Pemeliharaan dan Inventarisasi Sarana dan Prasarana SMP Negeri 255 Jakarta.

Pengorganisasian pemeliharaan sarana dan prasarana merupakan tahapan ketiga dalam teknik pemeliharaan sarana prasarana yang dilakukan oleh SMP Negeri 255 Jakarta. Dalam tahapan ini diketahui bahwa sekolah tidak punya struktur tim pengelolaan pemeliharaan sarana dan prasarana dan juga tak adanya pembagian peran yang jelas. Tim sarana dan prasarana yang dimiliki oleh SMP Negeri 255 Jakarta terdiri dari kepala sekolah sebagai penanggung jawab, wakil kepala sekolah bidang sarana dan prasarana sebagai ketua tim, dan 2 orang guru yang secara sukarela menjadi tim pelaksana.

(2) Pelaksanaan pemeliharaan sarana dan prasarana merupakan tahapan keempat dalam teknik pemeliharaan 
sarana prasarana yang dilakukan oleh SMP Negeri 255 Jakarta. Dalam tahap ini sekolah menemui hambatan seperti masalah keuangan karna berasal dari BOP dan BOS dan butuh rekanan tenaga ahli untuk perbaikan yang dapat dipercaya.

(3) Pencatatan inventarisasi sarana dan prasarana merupakan tahapan pertama dalam prosedur inventarisasi sarana prasarana yang dilakukan oleh SMP Negeri 255 Jakarta Dalam proses pencatatan sarana dan prasarana di SMP Negeri 255 Jakarta terdapat masalah yang sering kali terjadi, yaitu: barang yang dikirim tidak disertakan nilai perolehan dan tidak sesuai spesifikasinya, sehingga menghambat pelaksanaan pencatatan hingga akhirnya barang yang dikirim mengalami penundaan pencatatan.

\section{Kesimpulan dan Implikasi}

Berdasarkan hasil penelitian dari manajemen sarana dan prasarana di SMP Negeri 255 Jakarta, maka dapat ditarik kesimpulan sebagai berikut:

1. Pemeliharaan Sarana dan Prasarana Pendidikan

Wakil kepala sekolah dan tim sarana prasarana bertugas membuat perencanaan atau persiapan kegiatan penyadaran pemeliharaan sarana dan prasarana seperti membuat tata tertib penggunaan sarana prasarana, dan lain-lain. Kepala sekolah mensosialisasikan hasil perencanaan yang telah dibuat dan disepakati kepada stakeholders. Para guru yang berhadapan langsung dengan siswa/i juga akan melakukan sosialisasi lanjutan tentang penyadaran pemeliharaan. Pemahaman pemeliharaan sebenarnya hampir sama dengan penyadaran pemeliharaan. Untuk meningkatkan pemahaman pentingnya memelihara sarana dan prasarana pendidikan, sekolah memiliki 2 kegiatan pemahaman yang rutin dilakukan. Pertama, menjelaskan masalah yang dihadapi dalam pemeliharaan sarana prasarana, seperti perilaku buruk yang sering pengguna sarana prasarana lakukan. Kedua, menjelaskan program kegiatan pemeliharaan yang akan dilakukan kepada stakeholders, sehingga dapat menjadi perhatian bersama.

Di SMP Negeri 255 Jakarta tidak memiliki struktur organisasi dan pembagian peran yang detail. Meskipun begitu, tetapi sekolah tetap memiliki pengorganisasian sederhana, yakni kepala sekolah sebagai penanggung jawab, wakil kepala sekolah bidang sarana dan prasarana ketua, 2 orang guru yang secara sukarela menjadi tim sarana dan prasarana sebagai pelaksana pemeliharaan dan guru-guru lainnya sebagai pengawas penggunaan sarana prasarana di dalam kelas.

Untuk pemeliharaan berkala bertujuan untuk merawat sekaligus memperbaiki jika ada kerusakan agar sarana ada prasarana dapat berfungsi kembali sebagaimana mestinya. Kegiatan perawatan dapat dilakukan oleh warga sekolah sendiri, tetapi untuk perbaikan dilakukan oleh tenaga ahli. Program pemeliharaan berkala yang dilakukan oleh SMP Negeri 255 Jakarta adalah pemeliharaan meubelair, alat laboratorium, pemeliharaan alat elektronik, pemeliharaan dan perbaikan ruang kelas, ruang laboratorium, ruang perpustakaan, ruang media, ruang kepala sekolah, ruang guru, ruang tata usaha, ruang $\mathrm{BP} / \mathrm{BK}$, tempat ibadah, instalasi (air, listrik, internet dan telepon), kamar mandi (guru/karyawan dan siswa/i).

Pendataan dilakukan oleh Bendahara barang, yang dibantu 
dan diawasi oleh wakil kepala sekolah bidang sarana dan prasarana berserta timnya. Saat memonitoring jika memang ada tambahan pemeliharaan atau ada yang tidak dapat telaksana nantinya akan dilaporkan, laporannya dimasukkan ke dalam format monitoring. Setelah itu, dari hasil monitoring akan ditindaklanjuti dengan penyusunan rencana program sarana dan prasarana untuk tahun ajaran berikutnya.

2. Inventarisasi Sarana dan Prasarana Pendidikan

Yang bertugas melakukan inventarisasi sarana dan prasarana adalah bendahara barang dan kepala bagian tata usaha dibantu oleh tim sarana dan prasarana.

Saat pencatatan sarana dan prasarana sekolah terlebih dahulu menyesuaikan barang yang diterima dengan data/dokumennya, setelah itu sekolah juga harus segera mencatat dari mana asal barang dikirimkan dan tahun berapa barang diterima, lalu melakukan pencatatan barang inventaris yang diterima ke dalam buku induk inventaris dan buku pembantu.

Setelah pencatatan dan pengelompokkan barang usai, data barang-barang yang telah dicatat akan dimasukkan ke dalam sebuah database milik sekolah sebagai acuan daftar aktiva saranaprasarana sekolah.

Pemberian kode barang dimulai dengan menganalisis perolehan asal sarana dan prasarana yang dikirim. Selanjutnya adalah akan dikelompokan berdasarkan jenis barang. Terakhir, penulisan kode pada label dan menempel label tersebut pada barang.

Evaluasi ini dilakukan secara berkala, yaitu setiap satu tahun sekali dan dilakukan di tiap akhir tahun ajaran, tepatnya di Bulan Juni.

Tata cara pembuatan rekapitulasi barang inventarisasi, dibuat format yang sederhana tetapi mudah dipahami oleh semua pihak, biasanya berdasarkan sumber dan tahunnya. Rekapitulasi barang inventarisasi biasanya dibuat sesuai permintaan dan sumber/pemberi barang dan kewajiban sekolah di tiap akhir tahun ajaran.

Secara umum langkah-langkah yang SMP Negeri 255 Jakarta lakukan adalah, Menginventarisasikan keberadaan sarana dan prasarana yang ada, baik kondisi, jumlah, dan lain-lain. Mengumpulkan data pendukung seperti tanggal pengadaan, sumber pengadaan atau tanggapan pengguna sarana dan prasarana. Mengisi formulir evaluasi yang tersedia sesuai dengan kondisi yang sebenarnya. Merekapitulasi hasil evaluasi, baik data kualitatif maupun kuantitatif. Menarik kesimpulan mengenai keseluruhan sarana dan prasarana sekolah, apa sudah memenuhi standar atau belum. Melaporkan hasil evaluasi kepada pihak yang memerlukan.

3. Kendala Pemeliharaan dan Inventarisasi Sarana dan Prasarana Pendidikan

Kendala dalam pemeliharaan sarana dan prasarana, sekolah tidak punya struktur tim pengelolaan pemeliharaan dan juga tak adanya pembagian peran yang jelas. Masalah keuangan dan tidak adanya tenaga ahli untuk pemeliharaan.

Kendala dalam inventarisasi yang ditemukan, kadang saat barang dikirim ke sekolah tidak disertakan nilai perolehan dan tidak sesuai spesifikasinya. 
Saran

Berdasarkan hasil penelitian, kesimpulan, dan implikasi yang telah dilakukan, maka peneliti memberikan beberapa saran sebagai berikut:

1. Kepala Sekolah: Memperhatikan pemeliharaan sarana dan prasarana di sekolah, melakukan pengawasan terhadap pemeliharaan sarana dan prasarana dan lebih intensif untuk memberikan kesadaran kepada seluruh warga sekolah untuk memelihara sarana dan prasarana yang ada di sekolah.

2. Wakil Kepala Sekolah Bidang Sarana dan Prasarana: Diharapkan lebih meningkatkan aspek pengorganisasian pemeliharaan sarana dan prasarana. Pengorganisasian dan pembagian peran harus dibuat dan dipersiapkan, agar tidak menimbulkan miskomunikasi antar tim sarana dan prasarana.

3. Bendahara Barang: Bendahara barang memiliki peranan penting saat pendataan pemeliharaan sarana dan prasarana, terutama saat kegiatan inventarisasi sarana dan prasarana. Hendaknya bendahara barang harus lebih teliti dan rapih dalam pelaksanaan dan penyajian hasil pelaporan. Dalam pengkodean masih adanya kode inventaris sarana prasarana yang belum diperbaiki untuk meminimalisir adanya barang yang belum memliki kode, penggandaan kode dan ketidaksesuaian kode dengan keadaan sebenarnya.

4. Bagi peneliti lain: Hendaknya lebih kreatif dalam mengembangkan kajian penelitian dengan menggunakan metode dan teknik penelitian yang variatif agar informasi yang diperoleh lebih akurat dan lengkap dalam rangka memperkaya kajian manajemen sarana dan prasarana di lembaga pendidikan.

\section{Daftar Pustaka}

Bafadal, Ibrahim, 2004, Manajemen Perlengkapan Sekolah, Jakarta: Bumi Aksara.

Barnawi dan M. Arifin, 2012, Manajemen Sarana dan Prasarana Sekolah, Jogjakarta: Ar-Ruzz Media.

Gunawan Ary H, 2011, Administrasi Sekolah, Jakarta: PT Rineka Cipta.

Sagala, Syaifu, 2007, Manajemen Strategik dalam Peningkatan Mutu Pendidikan, Bandung: Alfabeta.

Soetjipto dan Raflis Kosasi, 2009, Profesi Keguruan, Jakarta: Rineka Cipta.

Sri Ambar Arum, Wahyu, 2007, Manajemen Sarana dan Prasarana Pendidikan, Jakarta: Multi Karya Mulia. 